\title{
International Arbitration of Maritime Delimitation: An Alternative for East Asia?
}

\section{Chao Wang *}

International arbitration, as a neutral, flexible, efficient and binding legal means of dispute resolution, has been effective in settling maritime delimitation disputes, especially in recent years since the UNCLOS came into force. There are a number of reasons (i.e. advantages) for its increased popularity. Reasonable expectations thus arise as to its applicability onto similar maritime delimitation disputes of the East Asian countries whose diplomatic efforts have mostly failed to address these matters. This article examines this practical issue primarily from the legal perspective by reviewing relevant international rules including the UNCLOS provisions on compulsory dispute resolution and cases such as the ongoing Philippines-China arbitration over the South China Sea. Observations are also made from the political and cultural perspectives as well. It concludes that, though multiple dispute settlement means are still encouraged, international arbitration could be an important alternative for East Asian countries seeking a peaceful solution to their maritime delimitation disputes.

\section{Keywords}

Maritime Delimitation, Dispute Resolution, International Arbitration, UNCLOS, Compulsory Procedures, East Asia

* Assistant professor at Zhejiang University Guanghua Law School, China. B.A. (Tsinghua), Ph.D. (CU Hong Kong). ORCID: http://orcid.org/0000-0001-5490-9218. This paper has been supported by China's National Social Sciences Research Funding Program (13CFX121) and the 985 Ocean Law Project of Zhejiang University. The author is grateful to his former colleagues Aloysius Llamzon, Yanying Li and Annie Lespérance at the Permanent Court of Arbitration in The Hague. The views expressed here are solely those of the author and are not to be attributed in any form to the PCA or the Chinese government. The usual disclaimer applies. The author may be contacted at: superwang@zju.edu.cn/ Address: Guanghua Law School, Zhejiang University, 51 Zhijiang Road, 310008, Hangzhou, China. 


\section{Introduction}

With the ever-increasing importance of the sea and marine resources, recently, more disputes have been witnessed arising from ocean development and usage, some of which are closely related to the traditional issue of maritime boundary delimitation. Contemporary international law, especially the 1982 United Nations Convention on the Law of the Sea ("UNCLOS") provides some general principles and methods for maritime delimitation. E.g., Articles 74 and 83 of the UNCLOS set out the delimitation of exclusive economic zones ("EEZ") and continental shelf boundaries between opposite or adjacent States. Meanwhile, international tribunals have adjudicated that the delimitation shall be effected by agreement on the international law basis and "by the use of practical methods capable of ensuring ... an equitable result." ${ }^{1}$ However, neither the UNCLOS, nor other international treaties stipulate specifically where the boundaries should be drawn; they do not offer a definitive answer as to the method that should be applied. As such, more than a few maritime delimitation disputes are still in deadlock.

The United Nations Charter requires disputes to be resolved through peaceful means such as negotiation, mediation, arbitration, and judicial settlement. ${ }^{2}$ The UNCLOS also provides its contracting States with the political and legal means for maritime dispute settlement. In addition to diplomatic methods, ${ }^{3}$ the Convention requires all disputes concerning its application or interpretation to be subject to the so-called "Compulsory Procedures Entailing Binding Decisions" as stipulated in Section 2 of Part XV; it provides four different means for the parties' selection. ${ }^{4}$ Moreover, if a party does not make any choice, the UNCLOS deems it to accept the arbitration mechanism, i.e., the dispute will automatically go to arbitration in accordance with Annex VII, unless the parties agree otherwise. ${ }^{5}$ As a consequence, recently, a remarkable number of maritime boundary delimitation disputes have been settled by international arbitration.

1 Delimitation of the Maritime Boundary in the Gulf of Maine Area (Can. v. U.S.), Judgment, 1984 I.C.J. $\uparrow 112$ (Oct. 12).

2 U.N. Charter art. 33, $\uparrow 1$.

3 UNCLOS art. 284.

4 These four means are: (1) adjudication before the International Court of Justice; (2) adjudication before the International Tribunal for the Law of the Sea; (3) arbitration under Annex VII; and (4) special arbitration under Annex VIII. See UNCLOS art. 287. On the dispute settlement mechanisms under the UNCLOS, see N. Klein, Dispute Settlement in the UN CONVENTiON ON the LaW of the SEA (2005).

5 UNCLOS art. 287, ๆ 5. 